\title{
In vivo Studies of Protein Binding of Ketorolac in Rat Model by UV-VIS Spectrophotometry and High Performance Liquid Chromatographic Methods
}

\author{
S. M. Rezaul Karim ${ }^{\psi}$, Sabiha Ferdowsy Koly, Md. Shah Amran \\ and Shaila Kabir \\ ${ }^{1}$ Department of Pharmaceutical Chemistry, Faculty of Pharmacy, University of Dhaka, Dhaka-1000, \\ Bangladesh
}

Received: May 18, 2016; Accepted: June 06, 2016; Published (web): June 20, 2016

\begin{abstract}
In this study, an attempt has been made to determine the protein binding of ketorolac at different time and concentration in rat model. A total of ten rats were used for this study. The rats were subdivided into two groups and $100 \mu \mathrm{g} / \mathrm{ml}$ and $200 \mu \mathrm{g} / \mathrm{ml}$ of ketorolac were administered through the intra-peritoneal route to rats of group 1 and group 2, respectively. The serum from the rats were collected and analyzed using UV-VIS spectrophotometry and HPLC. In the UV-VIS Spectrophotometric study, the highest percentage of protein binding for ketorolac was found to be $63.067 \%$ in group 1 and $74.63 \%$ in group 2. In case of HPLC method, the highest protein binding of ketorolac for group 1 and group 2 were $89.72 \%$ and $95.07 \%$, respectively. The observed protein binding percentage of ketorolac by HPLC method was slightly higher than that found in UV-VIS Spectrophotometric method. The result obtained in this study showed that the protein binding of ketorolac changes with the time and drug concentration. The percentage of protein binding was higher for higher drug concentration.
\end{abstract}

Key words: In vivo, Protein bonding, Ketorolac, Serum.

\section{INTRODUCTION}

Protein binding refers to the binding of a drug to plasma proteins. The interaction can also occur among the drug and tissue membranes, red blood cells and other components of the blood. The fraction of drugs bound to plasma protein is temporarily inactive. ${ }^{1}$ Protein binding is an important parameter to determine the pharmacokinetic and pharmacodynamic properties of drugs. This drug-protein interaction has great impact on bioavailability and toxicity of drugs. ${ }^{2-5}$ Acidic drugs will tend to bind to albumin which are basic and basic drugs will primarily bind to $\alpha$-glycoprotein, which are acidic. Acidic drugs may also bind to lipoproteins, if the albumin is saturated. ${ }^{6}$ Ketorolac is a potent nonsteroidal anti-inflammatory drug that is widely used

Correspondence to: Shaila Kabir Email: kabirshaila@gmail.com

${ }^{\psi}$ Current Address: Department of Pharmacy, Daffodil International University, Dhaka, Bangladesh

Dhaka Univ. J. Pharm. Sci. 15(1): 63-67, 2016 (June) in the treatment of moderate to severe pain ${ }^{7}$. It is also used in the treatment of post-surgery pain. But it produces gastric and duodenal ulcers. It has been reported that ketorolac produces its analgesic activity by inhibiting prostaglandin synthesis. ${ }^{8-9}$

The aim of the current work was to study the protein binding of Ketorolac to plasma proteins by two different methods, viz - UV spectrophotometry and HPLC and the obtained results were compared.

\section{MATERIALS AND METHODS}

Drugs and chemicals. Ketorolac was a kind gift from Incepta Pharmaceuticals Ltd., Bangladesh. All other reagents used were of analytical grade and purchased from the local suppliers.

Preparation of phosphate buffer pH 7.4. Phosphate buffer of $\mathrm{pH} 7.4$ was prepared by the method described by Perrin \& Boyd Dempsey. ${ }^{10}$ For this, $500 \mathrm{~mL}$ of $0.01 \mathrm{M}$ di-sodium hydrogen 
phosphate ( $\mathrm{MW}=141.96)$ solution was prepared in a volumetric flask (solution A) and then $500 \mathrm{ml}$ of 0.02 $\mathrm{M}$ potassium dihydrogen phosphate $(\mathrm{MW}=136.09)$ solution was prepared in another volumetric flask (solution B).

In order to prepare $1000 \mathrm{~mL}$ phosphate buffer of pH 7.4, approximately $290 \mathrm{~mL}$ of solution A was properly mixed with approximately $66 \mathrm{ml}$ of solution B. Finally the volume was adjusted to $1000 \mathrm{~mL}$ by adding demineralized water and the $\mathrm{pH}$ was checked by a $\mathrm{pH}$ meter.

Study design. The study was carried out following a randomized cross-over design. A total of 10 rats were used for the study. For the analysis of ketorolac, the rats were divided into two groups and each group received $100 \mu \mathrm{g} / \mathrm{ml}$ and $200 \mu \mathrm{g} / \mathrm{mL}$ of drug, respectively through intra-peritoneal injection. Then blood samples were taken at 60, 120, 180, 240 and 300 min after administration of each of the doses.

Preparation of rat serum. The blood was collected in a serum tube. The collected serum tube was allowed to settle down for about 1-2 minutes. As soon as the blood clotted, the serum tubes were placed in the centrifuge machine. The blood samples were centrifuged for 10 minutes at $4000 \mathrm{rpm}$. After the centrifugation process, the serum (supernatant) was collected in a fresh eppendorf tube by a micropipette. Then the serum was stored at $-20{ }^{\circ} \mathrm{C}$ until further analysis.

Determination of ketorolac in the serum by UV-VIS spectrophotometric technique. Serum sample $(50 \mu \mathrm{l})$ from each rat of the two groups was taken in separate test tubes. The final volume was adjusted to $5 \mathrm{ml}$ with phosphate buffer solution of $\mathrm{pH}$ 7.4. The solutions were then mixed by vortex machine for about 30 seconds. As a control sample, phosphate buffer solution of $\mathrm{pH} 7.4$ and the untreated rat serum was used. The absorbance values of the solutions were determined at $278 \mathrm{~nm}^{11}$ by a UV spectrophotometer (UV- 800, Shimadzu, Japan).

Determination of ketorolac in the serum by HPLC technique. The serum was stored frozen at $20{ }^{\circ} \mathrm{C}$ until analyzed by HPLC machine (model Prominence from Shimadzu, Japan equipped with
PDA detector and auto injector). Plasma ketorolac levels were determined as described by FloresMurrieta et al. ${ }^{12}$ Briefly, $1 \mathrm{ml}$ serum samples were acidified with $0.2 \mathrm{~mL}$ of $0.1 \mathrm{M}$ sodium acetate, at $\mathrm{pH}$ 4. This mixture was extracted twice with $5 \mathrm{ml}$ of diethyl ether by agitation with a vortex mixer. Organic layer was transferred to a conical tube and evaporated to dryness at $45{ }^{\circ} \mathrm{C}$ under a stream of nitrogen. The mobile phase was prepared by mixing o-phosphoric acid and acetonitrile in a ratio of $66: 34$ $(\mathrm{v} / \mathrm{v})$. The dry residue was redissolved in $1 \mathrm{ml}$ of mobile phase and $200 \mu \mathrm{l}$ aliquots were injected into the chromatographic system. Separation of the compounds was carried out in $15 \mathrm{~cm} \times 3.9 \mathrm{~mm}$ symmetry $\mathrm{C} 18$ column of $5 \mu \mathrm{m}$ particle size eluted with a mixture of $10 \mathrm{mM}$ monobasic sodium phosphate adjusted to $\mathrm{pH} 3$ with the mobile phase at a flow rate of $0.7 \mathrm{ml} / \mathrm{min}$. Detection was carried out at $313 \mathrm{~nm} .{ }^{12}$

Statistical analysis. Results were expressed as Mean \pm SD, where applicable.

\section{RESULTS AND DISCUSSION}

Determination of protein binding. The amount of drug bound to plasma protein is commonly defined as the percentage bound ${ }^{13}$, which is given by the following formula:

$$
\begin{gathered}
\mathrm{F}=\frac{[\text { Bound drug }]}{[\text { Total drug }]} \times 100 \% \\
\mathrm{~F}=\text { Percentage of protein binding }
\end{gathered}
$$

The signal [ ] signifies molar concentration

The formula determines the fraction of drug present in the plasma and bound to plasma protein. By using this formula, the percentage of protein binding was determined using the free drug concentration in the serum.

Protein binding of ketorolac by UV-VIS spectrophotometric method. The protein binding of ketorolac to rat serum for both the groups was studied by UV-VIS Spectrophotometric method at $\mathrm{pH} 7.4$ and $37^{\circ} \mathrm{C}$. Data of UV analysis showed a non-linear curve, suggesting that protein binding of ketorolac changes with time (Figure 1 and Table 1). 

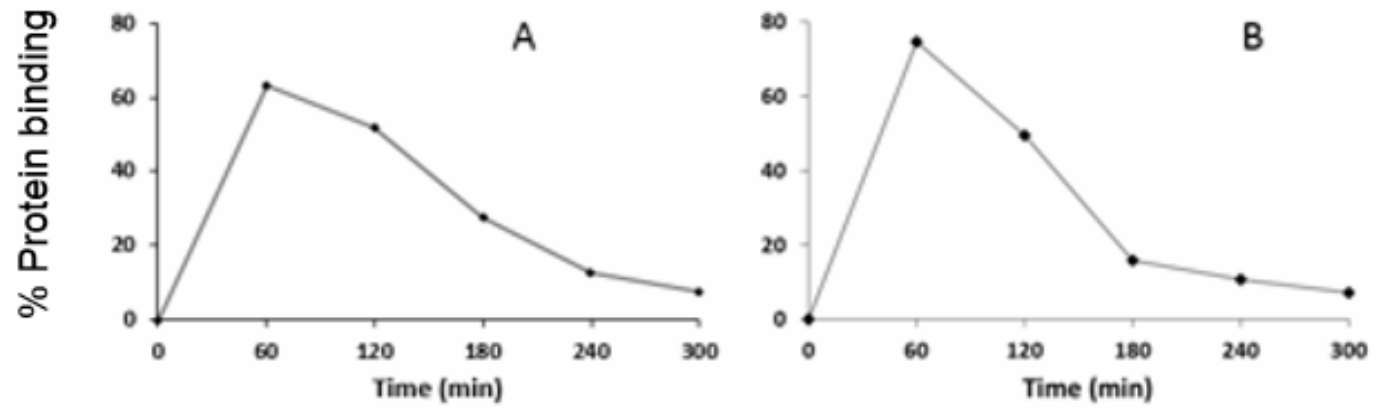

Figure 1. Percentage of protein binding of ketorolac at different time interval by UV-VIS spectrophotometry.

Table 1. Comparison of the protein binding phenomenon of ketorolac by UV-VIS spectrophotometric and HPLC methods.

\begin{tabular}{lllcc}
\hline $\begin{array}{l}\text { Name of the } \\
\text { drug }\end{array}$ & Group & Method & $\begin{array}{c}\text { Percentage of highest protein } \\
\text { binding }\end{array}$ & $\begin{array}{c}\text { Time of highest protein } \\
\text { binding (min) }\end{array}$ \\
\hline Ketorolac & 1 & UV-VIS Spectrophotometry & 63.07 & 60 \\
Ketorolac & 2 & UV-VIS Spectrophotometry & 74.63 & 60 \\
Ketorolac & 1 & HPLC & 89.72 & 60 \\
Ketorolac & 2 & HPLC & 95.07 & 60 \\
\hline
\end{tabular}

Spectrophotometric method. Panel A represents the protein binding of group 1 and panel $B$ represents the protein binding of group 2 rats.

The results of UV-VIS spectrophotometric analysis of group 1 indicated that ketorolac started to bind with blood plasma after the administration and the percentage of protein binding increased up to 60 minutes. The highest percentage of protein binding $(63.07 \%)$ was observed at the $60^{\text {th }}$ minute after administration. After that, the protein binding started to decrease and at the $300^{\text {th }}$ minute, the lowest protein binding value was found to be $7.14 \%$.

The results of UV-VIS spectrophotometric analysis of group 2 rats showed a similar pattern of protein binding with ketorolac. The protein binding was the highest at $60^{\text {th }}$ minute and the lowest at $300^{\text {th }}$ minute after administration of ketorolac in rats which were $74.63 \%$ and $7.41 \%$, respectively.

Protein binding of ketorolac by HPLC method. The binding of ketorolac to rat serum for both groups was studied by HPLC method. Data of HPLC analysis showed a non-linear curve, suggesting that protein binding changes with time. The results of HPLC analysis of group 1 indicated that ketorolac started to bind with blood plasma proteins after the administration and the percentage of protein binding increased up to 60 minutes. The highest percentage of protein binding $(89.72 \%)$ was achieved at the $60^{\text {th }}$ minute of administration. After that, the protein binding started to decrease and at the $300^{\text {th }}$ minute, lowest protein binding was observed (Figure 2).

The results of HPLC analysis of group 2 also indicated that ketorolac started to bind with blood plasma after the administration and the percentage of protein binding increased up to 60 minutes. The highest percentage of protein binding was 95.07\%, observed at the $60^{\text {th }}$ minute of administration. The protein binding started to decrease and at the $300^{\text {th }}$ minute, the lowest protein binding was observed and the percentage of protein binding was calculated from Figure 3 using data obtained with the original tracings that were not shown here (Figure 3, Figure 4 and Table 1). 


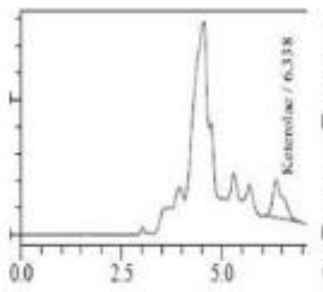

a

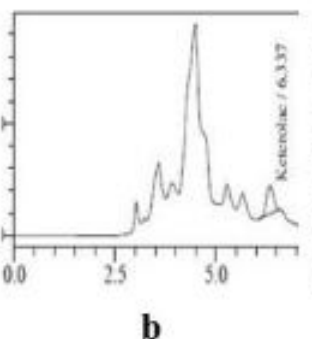

b

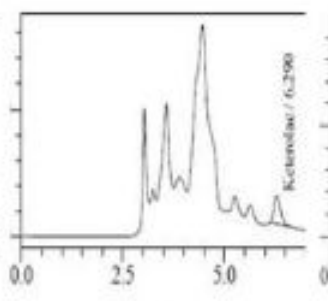

c

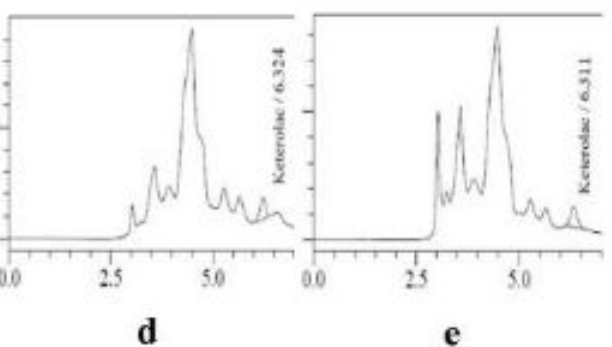

Figure 2. Chromatograms of ketorolac for group 1. Panel a: Chromatogram of ketorolac at 60 minutes, Panel b: Chromatogram of ketorolac at 120 minutes, Panel c: Chromatogram of ketorolac at 180 minutes, Panel d: Chromatogram of ketorolac at 240 minutes, Panel e: Chromatogram of ketorolac at 300 minutes.

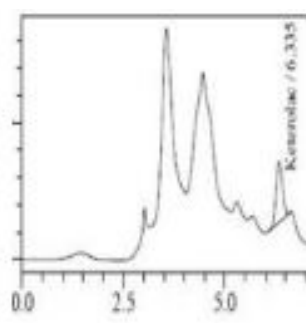

a

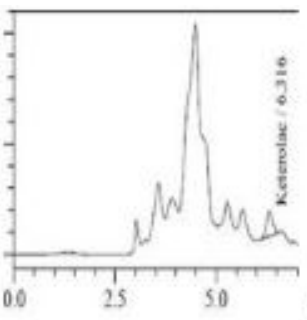

b

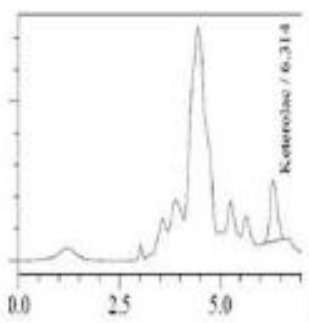

c

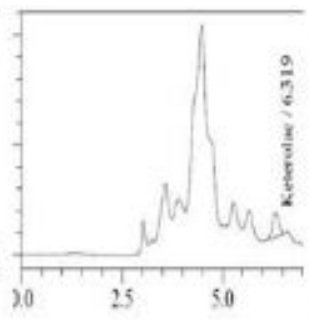

d

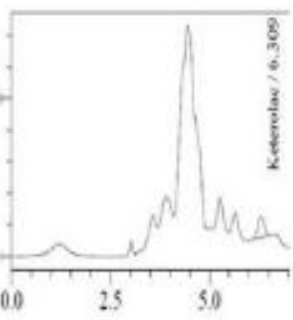

$\mathbf{e}$

Figure 3. Chromatograms of ketorolac for group 2. Panel a: Chromatogram of ketorolac at 60 minutes, Panel b: Chromatogram of ketorolac at 120 minutes, Panel c: Chromatogram of ketorolac at 180 minutes, Panel d: Chromatogram of ketorolac at 240 minutes, Panel e: Chromatogram of ketorolac at 300 minutes.
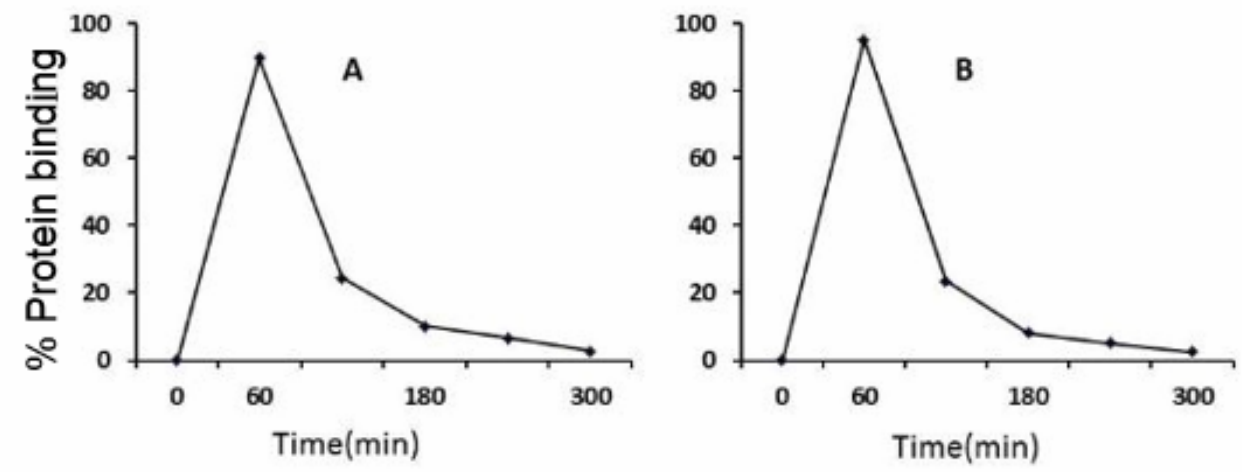

Figure 4. Percentage of protein binding of ketorolac at different time interval by HPLC method. Panel A represents the protein binding of group 1 and panel B represents the protein binding of group 2.

The binding of drugs to plasma proteins, in particular to serum albumin, is a matter of great concern as it can affect the pharmacokinetic properties of the drugs to a great extent. It is the phenomenon which determines the bioavailability of the drugs and the amount of active ingredient available at the site of action. There are various factors that can influence the protein binding of a drug.

The protein binding of ketorolac in rats observed from the above two techniques was compared after intra-peritoneal administration of $100 \mu \mathrm{g} / \mathrm{ml}$ and 200 $\mu \mathrm{g} / \mathrm{ml}$ of ketorolac. In this study, the highest protein binding observed for ketorolac by UV-VIS 
spectrophotometric method was $74.63 \%$ (Figure 1, panel B), and it was $95.07 \%$ (Figure 2, panel B) by HPLC method. So, results from both the methods indicated that the percentage of protein binding changed with time. In all the cases, the percentage of protein of binding has an increasing trend in the initial hours after administration. Then the percentage of protein binding started to decrease. Another important phenomenon is that the protein binding is directly proportional to drug concentration. The percentage of protein binding is higher for higher concentration of drugs.

\section{CONCLUSION}

Sample serum of rats was analyzed for the determination of protein binding of ketorolac. The highest percentage of protein binding was obtained at the initial hour of administration in all the cases. Both the methods (UV-VIS spectrophotometry and HPLC) showed the same pattern of protein binding.

\section{ACKNOWLEDGEMENT}

We would like to express our heartiest appreciation to Professor Dr. Sheikh Md. Nazrul Islam, IFNS, University of Dhaka, for permitting us to use their animal house.

\section{REFERENCES}

1. Shargel, L. and Andrew, Y. 2005. Applied Biopharmaceutics and Pharmacokinetics. Chapter 10 (Physiologic Drug Distribution and Protein Binding) (5th edition), pp. 253-602.

2. Mallick, A., Bera, S.C., Maiti, S. and Chattopadhyay, N. 2004. Fluorometric investigation of interaction of 3-acetyl-4oxo-6,7-dihydro-12H indolo-[2,3-a] quinolizine with bovine serum albumin. Biophys. Chem. 112, 9-14.

3. Ni, Y., Liu, G.L. and Kokot, S. 2011. Competitive binding of small molecules with biopolymers: a fluorescence spectroscopy and chemometrics study of the interaction of aspirin and ibuprofen with BSA. Analyst. 136, 4794-4801.
4. Gentili, P.L., Ortica, F. and Favaro, G. 2008. Static and dynamic interaction of a naturally occurring photochromic with bovine serum albumin studied by UV-visible absorption and fluorescence spectroscopy. J. Phys. Chem. B. 112, 16793-16801.

5. Kandagal, P.B., Ashoka, S., Seetharamappa, J., Shaikh, S.M., Jadegoud, Y. and Ijare, O.B. 2006. Study of the interaction of an anticancer drug with human and bovine serum albumin: spectroscopic approach. J. Pharm. Biomed. Anal. 41, 393-399.

6. Singlas, E. 1987. Protein binding of drugs: definitions. Modalities, effects and changes. Chapter 4 (Changes in plasma protein binding) (2nd edition), pp. 53-55.

7. Buckley, M.T. and Brogden, R.N. 1990. Ketorolac. A review of its pharmacodynamic and pharmacokinetic properties, and therapeutic potential. Drugs 39, 86-109.

8. Rooks, W.H.2 ${ }^{\text {nd }}$., Maloney, P.J., Shott, L.D., Schuler, M.E., Sevelius, H., Strosberg, A.M., Tanenbaum, L., Tomolonis, A.J., Wallach, M.B. and Waterbury, D. 1985. The analgesic and anti-inflammatory profile of ketorolac and its tromethamine salt. Drugs Exp. Clin. Res. 11, 479-492.

9. Domer, F. Characterization of the analgesic activity of ketorolac in mice. 1990. Eur. J. Pharmacol. 177, 127-135.

10. Horvath, C., Preiss, B. and Lipsky, R. 1967. Fast liquid chromatography, investigation of operating parameters and the separation of nucleotides, Analytical Chem. 39, 14221428.

11. Deepa, K.N., Hossain, M.K., Amran, M.S., and Kabir, S. 2014. In vitro model for studying Interactions between ketorolac and omeprazole with bovine serum albumin by UV-spectroscopic method. Bangladesh Pharmaceutical Journal. 17, 92-98.

12. Perez-Urizar, J., Aguilar-Cota, M. E., Herrera, J. E. and Flores-Murrieta, F. J. 2002. Comparative bioavailability of ketorolac tromethamine after intramuscular and sublingual Administration. Proc. West. Pharmacol. Soc. 45, 6-7.

13. Singlas, E. 1988. Protein binding of drugs-definition, modalities, effects, changes. Chapter 1 (Modalities of plasma protein binding) (2nd edition), pp. 17-18. 